\title{
U.S. Department of Energy (DOE) Technical Assistance to Beichuan Reconstruction: Creating and Designing Low- to Zero-carbon Communities in New Beichuan, Sichuan Province
}

\author{
Prepared by \\ T. Xu, C. Wang, T. Hong, and M. Levine \\ Lawrence Berkeley National Laboratory \\ Berkeley CA 94720 USA
}

October 29, 2009

\section{Introduction}

Beichuan county, located in north of Sichuan Province, was the most severely damaged township in last May's Sichuan earthquake. Reconstruction of a new Beichuan is a highprofiled project by the governments. In addition to constructing structurally-sound, quake-safe buildings in the new development, rebuilding Beichuan presents an opportunity for constructing new low- to zero-carbon communities in the region. In fact, building up greener communities in the reconstruction has become a top priority for the county, which, at an estimated 7 square $\mathrm{km}$, is expected to have 50,000 residents in 2015 and 70,000 in 2020 .

The recent focus of construction projects is on the east side of the river, while land on its west bank will be reserved for development in the mid- to long-term. In the near term, a number of new public buildings are scheduled to be constructed starting in November 2009. As indicated by the deputy county chief, Mr. He Wang, the construction timeframe is unusually tight. Many buildings, although in various stages of planning and design, will be constructed starting in November 2009. Timely expert advice on design improvement and planning considerations will benefit the integration of energy efficiency and environmental benign elements in Beichuan's reconstruction, and will help promoting integrated development of green communities with low- to zero-carbon emission from the region.

In order to create synergies and provide technical assistance with the support from US Department of Energy, LBNL sets the following goals with the theme of promoting green community development:

1. Help creating healthy and comfortable built environments

2. Advocate efficient use of natural resources in design and operation that would reduce costs and achieve zero-carbon emissions, and

3. Provide guides for integrated environmental planning and green design. 
In particular, we advocate an integration approach in planning, design and construction process for energy-efficient buildings, and provide quick recommendations for energy and environmental considerations so that the right decisions for design and construction are made in the process. For example, designing high-performance schools would not only use less energy, cost less to operate, and emit less energy-related pollutants and carbon than conventional buildings, but also would create better thermal environmental conditions conducive to learning for the occupants (e.g., students). Successful implementation of measures for zero-carbon emission may also be duplicative in the region and be a living teaching and learning tool for green development.

In Beichuan where it is cold in winter and sometimes hot in summer, no space heating is required for public buildings under current national building energy codes or design guides for the climate zone. Therefore, designing and delivering buildings that are conducive to people's comfort and health, while being a challenge, presents a unique opportunity to promote development of green communities with low- to zero-carbon emission.

\section{Purpose and Tasks}

Our purpose is to provide technical assistance in the building planning, design and construction phases to promote green communities in Beichuan Reconstruction. Specifically, we conducted design reviews, building performance analysis, and developed recommendations for design improvement and/or considerations. The main tasks undertaken include the following:

1) Identify Points of Contacts (POCs) for leading the project

2) Obtain building design information

- Local weather data

- Building designs and their characteristics

3) Outline and carry out a review plan

- Perform local weather analysis

- Review designs

- Obtain and review green building standards in China and the United States

4) Develop recommendations for design/planning

- Draft general recommendations for design and construction

- Perform building simulation to analyze thermal-environmental performance

- Finalize recommendations

5) Interact with POC of Beichuan Reconstruction and deliver summaries of the recommendations

- Provide draft recommendations

- Deliver final recommendations. 


\section{Project Outcomes and Accomplishments}

\section{Project teams were formulated with POCs identified.}

The LBNL team was formulated on September 22, 2009. LBNL Point of Contact (POC) to lead the project is Tim Xu, with technical assistance from Chuang Wang and Tianzhen Hong. Supervision was provided by Mark Levine. In addition to emailing to Construction Department of Sichuan Province, phone calls were made to communicate with designers, planners, and/or officials associated with Beichuan Reconstruction. As a result, we have identified Mr. He Wang as the Point of Contacts (POCs) for this Beichuan project. Mr. He is an architect and urban planner, and was appointed Deputy Chief of Beichuan County in charge of high-profiled Beichuan reconstruction. Mr. He leads a local Beichuan team in the planning-design-construction process, and is keen on implementing green planning and designs in the processes.

\section{Obtained building designs and weather data}

The weather data analysis is critical for reviewing and developing recommendations of local green building design and construction of various types in the Beichuan. LBNL has gathered weather data sets suitable for Beichuan region and developed pre-design analysis. Following phone discussion between the POCs, the Beichuan team has identified four project candidates that can benefit from LBNL's advice. Preliminary designs of four different buildings were then sent to LBNL for review.

\section{Outline and carry out a review plan}

\subsection{Summary of local weather analysis}

Predominant wind's directions and speeds in the region change with month and season of the year. Figure 1 shows the aggregated frequencies of wind speed per wind direction in a year. Except for summer months when NW wind becomes more evident, NE wind appears to be most dominant throughout the year with SE wind being secondary. Because the school is normally closed for summer vacation, we have examined ways of optimizing the school design to improve the building's thermal environmental performance when typical occupancies are expected. In hot summer months, SE winds are more common. In addition, based upon the TMY data, we have found that it is common to have natural winds in the region (e.g., over $60 \%$ of the time with detectable wind speeds).

The weather is generally mild during spring and fall, and becomes cold in winter and hot in summer (Figure 2). Annual heating-degree days are approximately 1500 HDDs and coolingdegree days up to 55 CDDs. Cooling load is normally not so demanding during occupancy hours in public buildings. Air humidity in the region is generally higher, e.g., 70-80\% RH. 


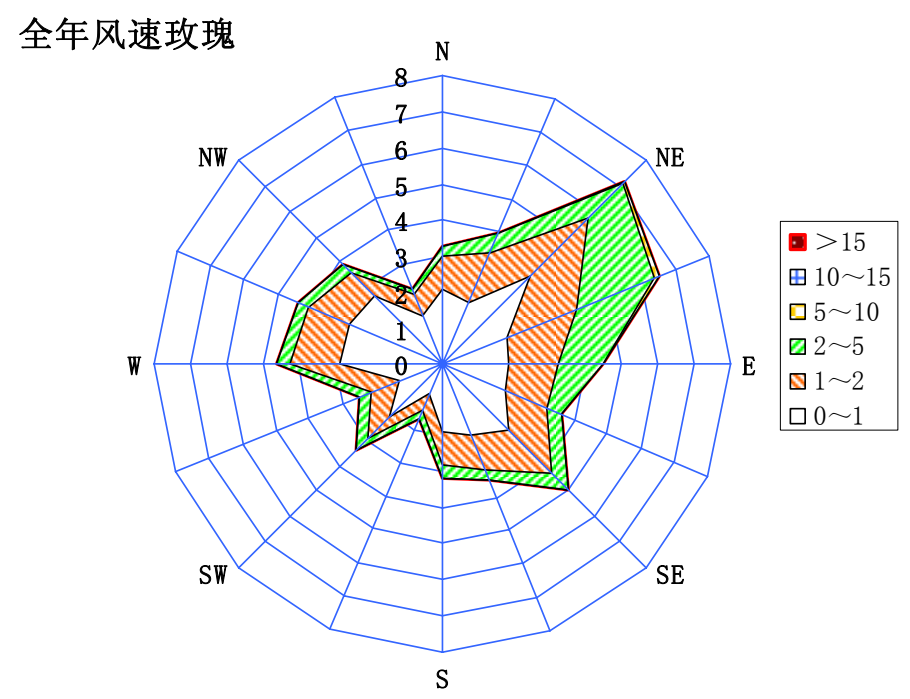

Figure 1 Wind Speed Distribution.

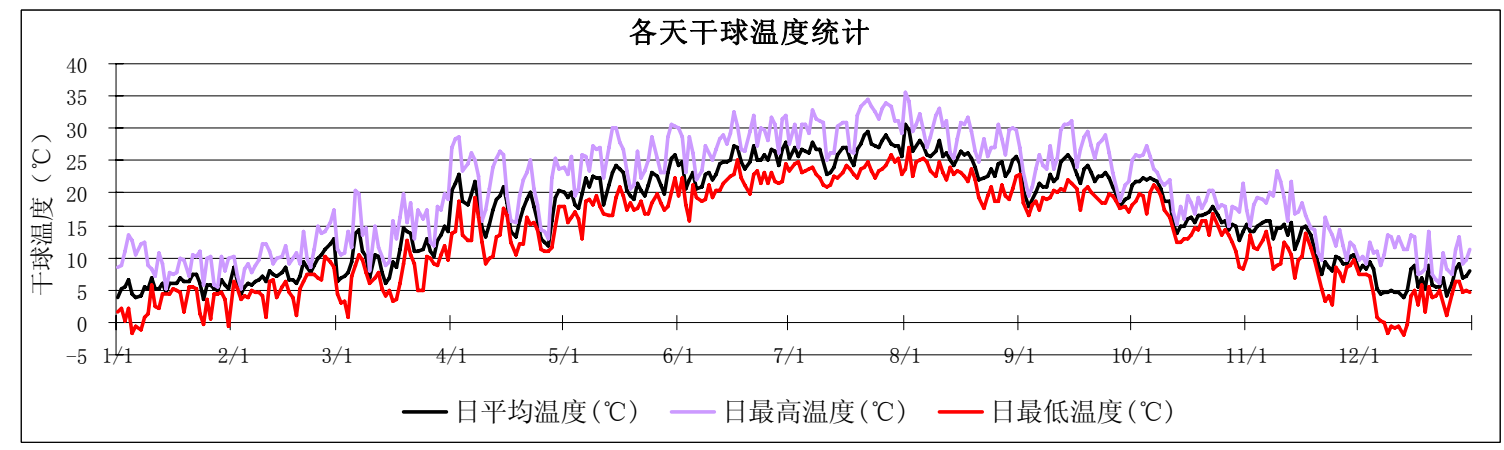

Figure 2 Average Daily Air Temperatures.

\subsection{Summary of building characteristics (four building types)}

Based upon the design and planning material received from the Beichuan team, Table 1 summarizes the key characteristics of the buildings. 
Table 1. Summary of public building information (Locations-all in Beichuan County)

\begin{tabular}{|c|c|c|c|c|c|}
\hline $\mathbf{N}$ & Building Name & \# of Bldgs & Туре & Story & $\begin{array}{l}\text { Total Floor } \\
\text { Area }\left(\mathbf{m}^{2}\right)\end{array}$ \\
\hline 1 & $\begin{array}{l}\text { Yong Chang } \\
\text { First } \\
\text { Elementary }\end{array}$ & $\begin{array}{l}\text { Classrooms } \\
\text { Dorm } \\
\text { Dining }\end{array}$ & Education & 3 & $\begin{array}{l}1,0340 \\
5,450 \\
3,350 \\
\text { Total } 19,000 \\
\end{array}$ \\
\hline 2 & Sports Center & $\begin{array}{l}\text { One outdoor field } \\
\text { complex } \\
\text { Training facility } \\
\text { gymnasium }\end{array}$ & $\begin{array}{l}\text { Public } \\
\text { Assembly } \\
\text { Sports }\end{array}$ & $\begin{array}{l}- \\
2-3 \\
\text { high- } \\
\text { ceiling }\end{array}$ & Typical \\
\hline 3 & $\begin{array}{l}\text { Qiang Cultural } \\
\text { Museum }\end{array}$ & $\begin{array}{l}\text { Library } \\
\text { Culture exhibition } \\
\text { Qiang Museum }\end{array}$ & $\begin{array}{l}\text { Public } \\
\text { Assembly }\end{array}$ & $1-4$ & $\begin{array}{l}3,500 \\
3,000 \\
8,000 \\
\\
\text { Total } 14,500\end{array}$ \\
\hline 4 & $\begin{array}{l}\text { People’s } \\
\text { Hospital }\end{array}$ & $\begin{array}{l}\text { Offices + hospital } \\
\text { complex }\end{array}$ & $\begin{array}{l}\text { Health } \\
\text { Care }\end{array}$ & $3-9$ & $\begin{array}{l}22,546 \\
+1424\end{array}$ \\
\hline
\end{tabular}

\subsection{Review of green building standards in China and the United States}

We have reviewed a number of relevant building standards or green building guidelines developed in the United States and in China. No single document provides complete information on design criteria for school buildings. In fact the available standard or green guide typically address a portion, if any, of the many parameters that affects the energy and thermal environmental performance for school buildings. For example, Table 2 summarizes the design criteria from existing green guides and building standards related to schools.

Table 2. Summary of design criteria from green guides and building standard for School

\begin{tabular}{|c|c|c|c|c|c|c|c|c|}
\hline & $\begin{array}{l}\text { Indoor } \\
\text { temp }\end{array}$ & $\begin{array}{l}\text { HVAC } \\
\text { Vent. }\end{array}$ & & $\begin{array}{l}\text { nvelop } \\
\text { W/m } / \mathbf{m}^{2} \mathbf{K} \\
\end{array}$ & & Window & & \\
\hline & ${ }^{\circ} \mathrm{C}$ & & $\begin{array}{l}\text { Ext } \\
\text { Wall }\end{array}$ & Roof & $\begin{array}{l}\text { Ext. } \\
\text { Door }\end{array}$ & $\begin{array}{l}\text { K/SC } \\
\left(\mathrm{W} / \mathrm{m}^{2} \mathrm{~K}\right)\end{array}$ & WF & operable \\
\hline $\begin{array}{l}\text { GB/T 50378- } \\
2006 \\
\text { Green bldg }\end{array}$ & $\begin{array}{l}\text { Refer to GB } \\
50189\end{array}$ & $\begin{array}{l}\text { Refer to GB } \\
50189\end{array}$ & - & - & - & - & - & $>30 \%$ \\
\hline $\begin{array}{l}\text { GB } 50189 \\
\text { Public bldg* }\end{array}$ & $\begin{array}{l}\text { Office } \\
\text { 16-20 Winter } \\
25 \text { Summer (no } \\
\text { school info) } \\
\end{array}$ & $\begin{array}{l}11 \text { ach } \\
\text { elementary } \\
\text { school }\end{array}$ & $\begin{array}{l}1.0 \\
\text { floor }\end{array}$ & 0.7 & - & $\begin{array}{l}\text { K2.5-4.7 } \\
\text { /SC0.4-0.55 } \\
\text { Pending } \\
\text { orientation }\end{array}$ & - & $\begin{array}{l}\text { Need } \\
\text { shading }\end{array}$ \\
\hline $\begin{array}{l}\text { JGJ 134- } \\
\text { 2001/J116-2001 } \\
\text { (Residential) }\end{array}$ & $\begin{array}{l}\text { 16-18 Winter } \\
\text { 26-28 Summer }\end{array}$ & 1 ach & $1.0-1.5$ & $0.8-1.0$ & 3 & $\begin{array}{l}\text { K2.5--4.7 } \\
\text { SC pending } \\
\text { orientation, } \\
\text { WW }\end{array}$ & & - \\
\hline $\begin{array}{l}\text { GBJ99-86 } \\
\text { (School) }\end{array}$ & $\begin{array}{l}16-18 \\
\text { classroom } \\
18 \text { library }\end{array}$ & $\begin{array}{l}3 \text { ach } \\
2.5 \text { ach dorm }\end{array}$ & - & - & - & 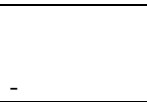 & $>1: 6$ & - \\
\hline
\end{tabular}




\begin{tabular}{|l|l|l|l|l|l|l|l|l|}
\hline $\begin{array}{l}\text { ASHRAE 90.1- } \\
\text { 2004 } \\
\text { nonresidential }\end{array}$ & & & $\begin{array}{l}0.857 \\
0.607\end{array}$ & $\begin{array}{l}0.36 \\
0.19 \\
\text { attic }\end{array}$ & 3.97 & $\begin{array}{l}\text { K2.67-3.8 } \\
\text { /SHGC }\end{array}$ & - & - \\
\hline $\begin{array}{l}\text { ASHRAE 189.1 } \\
\text { green bldg }\end{array}$ & - & & & & & & & \\
\hline $\begin{array}{l}\text { ASHRAE } \\
\text { handbook }\end{array}$ & $\begin{array}{l}\text { Classroom } \\
\text { 22-24 Winter } \\
\text { 26 Summer }\end{array}$ & - & - & - & - & - & - & - \\
\hline
\end{tabular}

* Assumes central systems only; no space heating enforced for the region; few guidelines applicable to school buildings.

\section{Develop recommendations for design/planning}

Upon our reviews of the regional weather data and design information provided by Beichuan team, we have developed a list of general recommendations for all buildings, and conducted additional performance analysis of one school building in Beichuan using DOE's EnergyPlus simulation program. The results from simulation analysis allow us to develop further recommendations and guidelines for school design and construction in the region, as compared to existing green design guides or standards in China and in the US.

Critical recommendations related to environmental quality and safety, if any, have been conveyed to the Beichuan team for design improvement and considerations based upon the review and analysis of available designs. Two draft reports on the list of recommendations were developed and delivered on October 9 (English version) and October 28 (Chinese version). The final reports with a refined list of recommendations were completed on October 29, 2009, ahead of the targeted November deadline.

\subsection{Summary of Recommendations}

In general, building envelop is a main factor in affecting thermal environmental performance of a building, and has significant impact on energy use especially when HVAC is included. Implementing good building envelope technologies available today make buildings more efficient, durable, comfortable, and adaptable. When required, HVAC design should consider interrelated building systems and energy-efficient designs often need smaller HVAC systems. Careful planning and efficient use of natural resources (e.g., water) for various purposes should be integrated. Table 3 enlists the recommendations, when applicable, for all buildings. 
Table 3. Design considerations for achieving green planning, design, and construction.

\begin{tabular}{|c|c|c|c|c|c|}
\hline & $\begin{array}{l}\text { Measure and Design } \\
\text { Considerations }\end{array}$ & School & $\begin{array}{l}\text { Culture } \\
\text { center }\end{array}$ & $\begin{array}{l}\text { Sports } \\
\text { facilities }\end{array}$ & Hospital \\
\hline \multirow[t]{3}{*}{$\begin{array}{l}\text { Indoor } \\
\text { Environmental } \\
\text { Quality } \\
\end{array}$} & Operable windows & $\mathrm{x}$ & $\mathrm{x}$ & $\mathrm{x}$ & some \\
\hline & $\begin{array}{l}\text { Non- or low-VOCs from paints and } \\
\text { furnishings }\end{array}$ & $\mathrm{x}$ & $\mathrm{x}$ & $\mathrm{x}$ & $\mathrm{x}$ \\
\hline & Non-lead paints and furnishings & $\mathrm{x}$ & $\mathrm{x}$ & $\mathrm{x}$ & $\mathrm{x}$ \\
\hline \multirow[t]{3}{*}{ Water usage } & $\begin{array}{l}\text { Irrigation water vs. drinking water } \\
\text { Controllable low-flow } \\
\text { sprinkler/dripping }\end{array}$ & $\mathrm{x}$ & $\mathrm{x}$ & $\mathrm{x}$ & $\mathrm{x}$ \\
\hline & Low-flow faucets, toilets & $\mathrm{x}$ & $\mathrm{x}$ & $\mathrm{x}$ & some \\
\hline & Landscape & - & - & $\begin{array}{l}\text { artificial } \\
\text { turf }\end{array}$ & - \\
\hline \multirow[t]{2}{*}{$\begin{array}{l}\text { Orientation } \\
\text { and natural } \\
\text { resources }\end{array}$} & $\begin{array}{l}\text { Re-orientation of existing } \\
\text { design/layouts to take advantage of } \\
\text { NE/SE winds to Maximize natural } \\
\text { ventilation }\end{array}$ & $\mathrm{x}$ & $\mathrm{x}$ & $\mathrm{x}$ & some \\
\hline & $\begin{array}{l}\text { Direct exhaust air, air-borne } \\
\text { contaminant dispersion to non- } \\
\text { occupied spaces }\end{array}$ & - & - & - & $\mathrm{x}$ \\
\hline \multirow[t]{2}{*}{$\begin{array}{l}\text { Exterior } \\
\text { Material } \\
\end{array}$} & $\begin{array}{l}\text { The cool (e.g., white) roof reflects } \\
\text { solar radiation, reducing the heat } \\
\text { island effect and internal cooling } \\
\text { loads. }\end{array}$ & $\mathrm{x}$ & $\mathrm{x}$ & $\mathrm{x}$ & $\mathrm{x}$ \\
\hline & $\begin{array}{l}\text { Use light exterior colors with higher } \\
\text { reflectance and high emittance to } \\
\text { reduce solar heat gains }\end{array}$ & $\mathrm{x}$ & $\mathrm{x}$ & $\mathrm{x}$ & $\mathrm{x}$ \\
\hline \multirow[t]{4}{*}{ Envelope } & $\begin{array}{l}\text { Apply sufficient insulation to exterior } \\
\text { walls, roofs, and floors }\end{array}$ & $\mathrm{x}$ & $\mathrm{x}$ & $\mathrm{x}$ & $\mathrm{x}$ \\
\hline & Maintain thermal mass & - & $\mathrm{x}$,museum & - & - \\
\hline & $\begin{array}{l}\text { Optimize building shapes to have a } \\
\text { smaller shape coefficient }\end{array}$ & $\mathrm{x}$ & $\mathrm{x}$ & $\mathrm{x}$ & $\mathrm{x}$ \\
\hline & $\begin{array}{l}\text { Design window-wall-ratio within } \\
40 \% \text { or less }\end{array}$ & $\begin{array}{l}\text { class } \\
\text { room up } \\
\text { to } 60 \%\end{array}$ & $\mathrm{x}$ & $\mathrm{x}$ & $\mathrm{x}$ \\
\hline \multirow[t]{3}{*}{ Fenestration } & $\begin{array}{l}\text { Avoid large windows facing west } \\
\text { without shading device }\end{array}$ & $\mathrm{x}$ & $\mathrm{x}$ & $\mathrm{x}$ & $\mathrm{x}$ \\
\hline & $\begin{array}{l}\text { Design exterior shading for west- } \\
\text { facing and south-facing window }\end{array}$ & $\mathrm{x}$ & $\mathrm{x}$ & $\mathrm{x}$ & $\mathrm{x}$ \\
\hline & $\begin{array}{l}\text { Use high-performance double- } \\
\text { glazing windows with low-e } \\
\text { coatings. The windows have low U- } \\
\text { factor, low SHGC, and reasonable } \\
\text { visible transmittance for daylighting. }\end{array}$ & $\mathrm{x}$ & $\mathrm{x}$ & & $\mathrm{x}$ \\
\hline $\begin{array}{l}\text { Other } \\
\text { Structures }\end{array}$ & Add shaded corridors & $\mathrm{x}$ & $\mathrm{x}$ & $\mathrm{x}$ & $\mathrm{x}$ \\
\hline
\end{tabular}




\begin{tabular}{|c|c|c|c|c|c|}
\hline & $\begin{array}{l}\text { Measure and Design } \\
\text { Considerations }\end{array}$ & School & $\begin{array}{l}\text { Culture } \\
\text { center }\end{array}$ & $\begin{array}{l}\text { Sports } \\
\text { facilities }\end{array}$ & Hospital \\
\hline & Vent exhaust from attics & $\mathrm{x}$ & $\begin{array}{l}\text { when } \\
\text { applicable }\end{array}$ & $\begin{array}{l}\text { when } \\
\text { applicable }\end{array}$ & $\mathrm{x}$ \\
\hline \multirow[t]{2}{*}{ Daylighting } & $\begin{array}{l}\text { Maximize day-lighting and controls } \\
\text { to reduce electric lighting while } \\
\text { keeping daylight glare under control }\end{array}$ & $\mathrm{x}$ & $\mathrm{x}$ & $\mathrm{x}$ & $\mathrm{x}$ \\
\hline & Appropriate sky-lighting & $\begin{array}{l}\mathrm{x} \\
\text { library }\end{array}$ & $\mathrm{x}$ library & no & $\mathrm{x}$ \\
\hline \multirow[t]{5}{*}{$\begin{array}{l}\text { Electric } \\
\text { Lighting }\end{array}$} & $\begin{array}{l}\text { Use programmable timing control to } \\
\text { reduce electrical lighting }\end{array}$ & $\mathrm{x}$ & $\mathrm{x}$ & $\mathrm{x}$ & $\mathrm{x}$ \\
\hline & $\begin{array}{l}\text { Use occupancy sensor controls to } \\
\text { reduce electrical lighting }\end{array}$ & $\begin{array}{l}\mathrm{x} \text {, hall } \\
\text { ways }\end{array}$ & $\mathrm{x}$ & no & no \\
\hline & $\begin{array}{l}\text { Include dimming control to reduce } \\
\text { electrical lighting }\end{array}$ & maybe & $\mathrm{x}$ & $\mathrm{X}$ & no \\
\hline & $\begin{array}{l}\text { Use efficient CFL lamps and fixtures } \\
\text { such as T8 and T5 lamps (indoor) }\end{array}$ & $\mathrm{x}$ & $\mathrm{x}$ & $\mathrm{x}$ & $\mathrm{x}$ \\
\hline & $\begin{array}{l}\text { Use LED lamps for outdoor and } \\
\text { signs lighting }\end{array}$ & $\mathrm{x}$ & $\mathrm{x}$ & $\mathrm{x}$ & $\mathrm{x}$ \\
\hline \multirow[t]{11}{*}{ HVAC } & $\begin{array}{l}\text { Variable-speed ceiling fans (safe, } \\
\text { low-speed) }\end{array}$ & $\mathrm{x}$ & $\mathrm{x}$ & $\mathrm{x}$ & - \\
\hline & $\begin{array}{l}\text { Consider demand control mechanical } \\
\text { ventilation }\end{array}$ & $\mathrm{x}$ & $\mathrm{x}$ & $\mathrm{x}$ & $\mathrm{x}$ \\
\hline & $\begin{array}{l}\text { Select appropriate HVAC system } \\
\text { type (including mechanical vent. } \\
\text { only), zoning, and controls }\end{array}$ & no AC & $\mathrm{x}$ & $\mathrm{x}$ & $\mathrm{x}$ various \\
\hline & $\begin{array}{l}\text { Use radiant cooling and heating } \\
\text { systems }\end{array}$ & & $\mathrm{x}$, museum & $\mathrm{x}$, gym & some \\
\hline & $\begin{array}{l}\text { Use air-side and water-side } \\
\text { economizers }\end{array}$ & & $\mathrm{X}$ & $\mathrm{x}$ & $\mathrm{x}$ \\
\hline & $\begin{array}{l}\text { Use variable speed drives for fans } \\
\text { and(or) pumps }\end{array}$ & & $\mathrm{X}$ & $\mathrm{x}$ & $\mathrm{x}$ \\
\hline & $\begin{array}{l}\text { Use high efficient chillers and } \\
\text { variable speed chillers. }\end{array}$ & & - & $\mathrm{x}$ & $\mathrm{x}$ \\
\hline & $\begin{array}{l}\text { Use multiple chillers instead of a } \\
\text { single large one }\end{array}$ & & $\begin{array}{l}\text { if } \\
\text { necessary }\end{array}$ & $\mathrm{x}$ & $\mathrm{x}$ \\
\hline & $\begin{array}{l}\text { Use reset controls to adjust supply air } \\
\text { rates and temperatures, fan static } \\
\text { pressure set point }\end{array}$ & & $\mathrm{x}$ & $\mathrm{x}$ & $\mathrm{x}$ \\
\hline & $\begin{array}{l}\text { Use reset controls to adjust chilled } \\
\text { water temperatures }\end{array}$ & & $\begin{array}{l}\text { if } \\
\text { necessary }\end{array}$ & $\mathrm{x}$ & $\mathrm{x}$ \\
\hline & $\begin{array}{l}\text { Control optimal hot water supply } \\
\text { temperature, and condenser water } \\
\text { temperature }\end{array}$ & & $\begin{array}{l}\text { if } \\
\text { necessary }\end{array}$ & $\mathrm{x}$ & $\mathrm{x}$ \\
\hline \multirow[t]{3}{*}{ Boiler } & $\begin{array}{l}\text { Use high efficient boilers such as } \\
\text { condensing boilers. }\end{array}$ & $\mathrm{x}$ & $\mathrm{x}$ & $\mathrm{x}$ & $\mathrm{x}$ \\
\hline & $\begin{array}{l}\text { Use multiple boilers instead of a } \\
\text { single large one }\end{array}$ & $\mathrm{x}$ & $\mathrm{x}$ & $\mathrm{x}$ & $\mathrm{x}$ \\
\hline & Use heat recovery & $\mathrm{x}$ & $\mathrm{x}$ & $\mathrm{x}$ & $\mathrm{x}$ \\
\hline
\end{tabular}

X: applicable; planning and design of the four buildings are illustrated in Figures 3 through 6 in Appendix.

In addition, the following considerations shall be included for planning and designs. 
$>$ Bus stops and public transportation integration

$>$ Bicycle parking spaces

$>$ Additional shades and shelters to the parking spaces

$>$ Shaded porches and walkways around the buildings

$>$ South-facing windows with high SHGC ratings to provide a building with heat in the winter

$>$ Properly designed roof overhang or corridors may reduce the solar heat gain from south- or west-facing windows in the summer

$>$ Include easy post-construction addition of window coverings - shades, blinds, mesh screens, and awnings, which will reduce solar heat gain in the summer

$>$ Fire safety and emergency measures and equipment

$>$ Space and facility of battery-chargers for electric vehicles

$>$ User-friendly designs for persons with disability should be advocated and implemented indoors and outdoors for all buildings, e.g., ramps for handicapped access to and within all buildings.

Hospital design should brace for possible outbreaks of diseases like bird flu that leap the species barrier from animals to humans. Lessons learned from SARS, H1N1, mad cow disease, and other illnesses should be integrated for coping with such outbreaks.

Due to the tight schedule and limited resource, it is impossible to develop detail recommendations for the hospital. However, one critical aspect in hospital design and space planning is to avoid potential cross-contamination caused by either improper system control or by improper exhaust or space allocations. For example, infection control and isolation can be compromised when the door from the isolated patient's room is opened. An anteroom maybe recommended as a means of controlling airborne contaminant concentration through containment and air dilution. While proper air handling and ventilation control is necessary in surgical services, airborne infection isolation spaces, protective environment rooms, laboratories, local exhaust systems for hazardous agents, and other special areas, the existing design and layout of infection clinics offices and isolation rooms for treatments may pose risks in cross-contamination to the adjacent spaces with neighboring windows.

The concerns about the existing design of infection clinics and treatment had been conveyed to Beichuan POC earlier. We recommend that design and planning improvement be made to avoid potential risks.

\subsection{Additional Guide for School Design though Performance Simulation and Analysis}

High-performance schools are comfortable, healthy learning environments that integrate indoor environmental quality, natural and electric lighting, comfort, acoustics, local climates, and safety. In the US, the CHPS (Collaborative for High Performance Schools) organization developed best practices manuals, available for free download at www.CHPS.net, for designing high performance schools. The CHPS design scorecard is attached in the Appendix for reference. 
Besides the general recommendations for school buildings, we aim at developing important guidelines based upon energy simulations using EnergyPlus program. Our analysis is focused on thermal environmental performance improvements for school buildings through optimizing building design in the local weather. The goal is to improve student comfort levels in the newly built learning environment, while greatly reducing and even eliminating energy use for space conditioning compared to state-of-the-arts schools in open literatures.

Based upon the weather data analysis of the region and building performance simulations using Energy Plus, we recommend the following guidelines in planning and designing school buildings in Beichuan region:

$>$ Enhance natural ventilation and daylight whenever appropriate for weather and seasonal conditions.

$>$ Implement glare control while maximize natural daylight.

$>$ Increase windows area with proper shading designs, and utilize ceiling fans to avoid overheat in summer.

$>$ Improve enclosure insulations (wall, roof, windows, doors) and minimize infiltrations to avoid heating requirement during winter.

Key measures include:

$>$ Design with larger windows to allow maximal daylight penetration, with window to wall ratio up to $60 \%$. WW ratio should be no less than $40 \%$.

$>$ Double-glass would be recommended when budget permits.

$>$ While single-layer-glass windows for classrooms are acceptable, measures must be taken to obtain and install highest-quality windows that have minimal unintended infiltration or leakage, and avoid condensations.

$>$ Avoid using horizontal sliding windows for classrooms.

$>$ North-facing windows should be no larger than south-facing windows, if not equivalent. External shading should be provided for south-facing and west-facing windows.

In case air conditioning is required for specific applications, central systems shall be avoided.

\section{Interact with POC of Beichuan Reconstruction and deliver a summary of the recommendations.}

Communications on LBNL recommendations were performed via phone calls and emails. LBNL is interested in learning about the planning-design-construction development and decision-making processes from the Beichuan team. The final reports on recommendations are completed, in both Chinese and English versions. They are delivered to the Beichuan POC by October 29, 2009. 
Acknowledgement: This work is supported by Mark Ginsberg, Office of Energy Efficiency and Renewable Energy (EERE), U.S. Department of Energy, under Contract No. DE-AC02-05CH11231. 


\section{Appendix A - CHPS Design Scorecard}

\begin{tabular}{|c|c|c|c|c|c|c|}
\hline \multirow{9}{*}{ 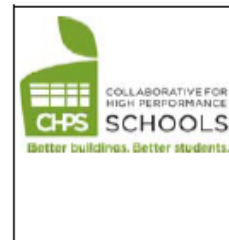 } & \multicolumn{6}{|c|}{ Collaborative for High Performance Schools (CHPS) Designed Scorecard } \\
\hline & \multicolumn{6}{|c|}{ Based on the 2009 Edition For New School Construction } \\
\hline & \multicolumn{6}{|c|}{ School Name: } \\
\hline & \multicolumn{6}{|c|}{ Expected Completion: } \\
\hline & \multicolumn{6}{|c|}{ School District. } \\
\hline & \multicolumn{6}{|c|}{ School Address: } \\
\hline & \multicolumn{6}{|c|}{ school contactiprincipal: } \\
\hline & \multicolumn{6}{|c|}{ student Capacity: } \\
\hline & \multicolumn{6}{|c|}{ Approximate Square Feet: } \\
\hline \multicolumn{7}{|l|}{ Verification } \\
\hline \multicolumn{7}{|c|}{ Is thla the frnal CHPS scorecard? YES or NO (Please circle) } \\
\hline \multicolumn{7}{|c|}{ Reglistered Principal Architect(SIgnature) } \\
\hline \multicolumn{6}{|l|}{ Name, Title, Date (Please print) } & Name, Trtie, Date (Please print) \\
\hline 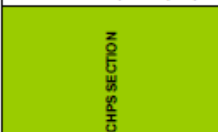 & 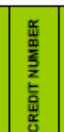 & 㞾 & 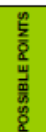 & 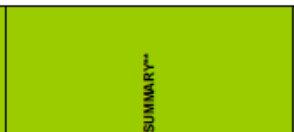 & 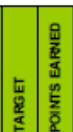 & 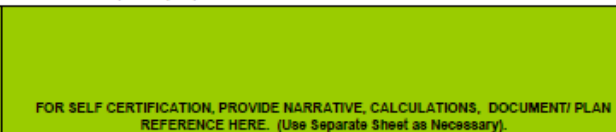 \\
\hline \multicolumn{7}{|c|}{ 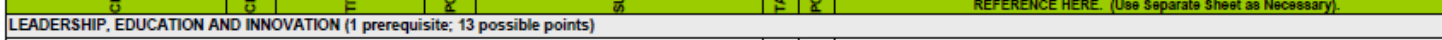 } \\
\hline \multirow[t]{2}{*}{ 1. Losderchip (4) } & LEI1.1 & District Level Commintment & $1-2$ & 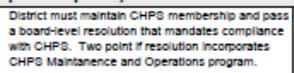 & & Arod Namase \\
\hline & LE11.2 & Initegrated Desilgn & $1-2$ & 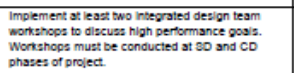 & & \\
\hline \multirow[t]{2}{*}{2 . Bohoolk se Loarning Toole (1) } & LE12.0 & Eousabonal DGpily & Rea & 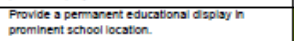 & $\mathrm{x}$ & \\
\hline & LE12.1 & Demonstration Necas & 1 & Frovide at leas: Eree educason demonstration & & \\
\hline \multirow[t]{2}{*}{ 3. Innovation (8) } & LEI3.1 & Innovason & 14 & $\begin{array}{l}\text { Impiement new vechnolopies or atraseges that } \\
\text { Wuther Wigh performance posas. }\end{array}$ & & \\
\hline & $\overline{L E 13.2}$ & $\begin{array}{l}\text { Deegen for Adsctabilly, } \\
\text { Durablity and }\end{array}$ & 24 & 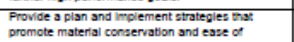 & & \\
\hline \multicolumn{7}{|c|}{ SUSTAINABLE SITES (2 prerequisites; 14 possible points) } \\
\hline \multirow[t]{6}{*}{ 1. site solibotion (6) } & 301.0 & Code compliance & Rea & 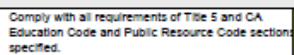 & $x^{x}$ & \\
\hline & उस1.1 & $\begin{array}{l}\text { Enwronmentaly Senzitive } \\
\text { Land }\end{array}$ & 1 & 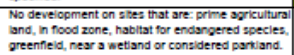 & & \\
\hline & $\overline{301.2}$ & Centra Location & 1 & 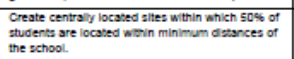 & & \\
\hline & $\overline{301.3}$ & Jointuge of Facilites & 1 & 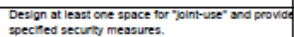 & & \\
\hline & 301,4 & Jontube of Parks & 1 & Ohare park or rectreation apace. & & \\
\hline & 331.5 & Reduced Footornt & 1 & Reduce the buliding footirnh & & \\
\hline \multirow[t]{3}{*}{ 2. Trancportation (3) } & 302.1 & PLalic Trangportason & 1 & Locate ness public transportaton. & & \\
\hline & 302.2 & $\begin{array}{l}\text { Human Powered } \\
\text { Traraporation }\end{array}$ & 1 & 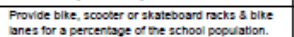 & & \\
\hline & $\overline{302.3}$ & Minimize Parking & 1 & $\begin{array}{l}\text { Mnimizze parring los \& create preteresed parking for } \\
\text { carpooss. }\end{array}$ & & \\
\hline \multirow[t]{3}{*}{ 3. stormwater Mansooemsent (2) } & 303.0 & $\begin{array}{l}\text { Conessuction Mite Runotr } \\
\text { Control }\end{array}$ & Rea & 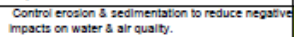 & $x$ & \\
\hline & $\overline{303.1}$ & Limit Stormwaser Runof & 1 & Mnimzen nunot: & & \\
\hline & 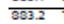 & Tres: assemwater Runof & 1 & Trestrunof: & & \\
\hline \multirow[t]{3}{*}{ 4. Outdoor surtacose \& spaose (3) } & 304.1 & $\begin{array}{l}\text { Reduce Hest lisands- } \\
\text { Landecaping lssues }\end{array}$ & 1 & 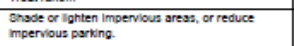 & & \\
\hline & 304.2 & $\begin{array}{l}\text { Reouce Hest IIIands- } \\
\text { Cool Roots }\end{array}$ & 1 & Intall cool or green roof. & & \\
\hline & $\overline{304.3}$ & School Gsorden & 1 & 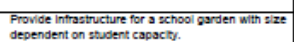 & & \\
\hline SOutdoor Lighting (1) & 305.1 & Lom Polluson Reostion & 1 & Mnlmze outroor lilumination. & & \\
\hline
\end{tabular}




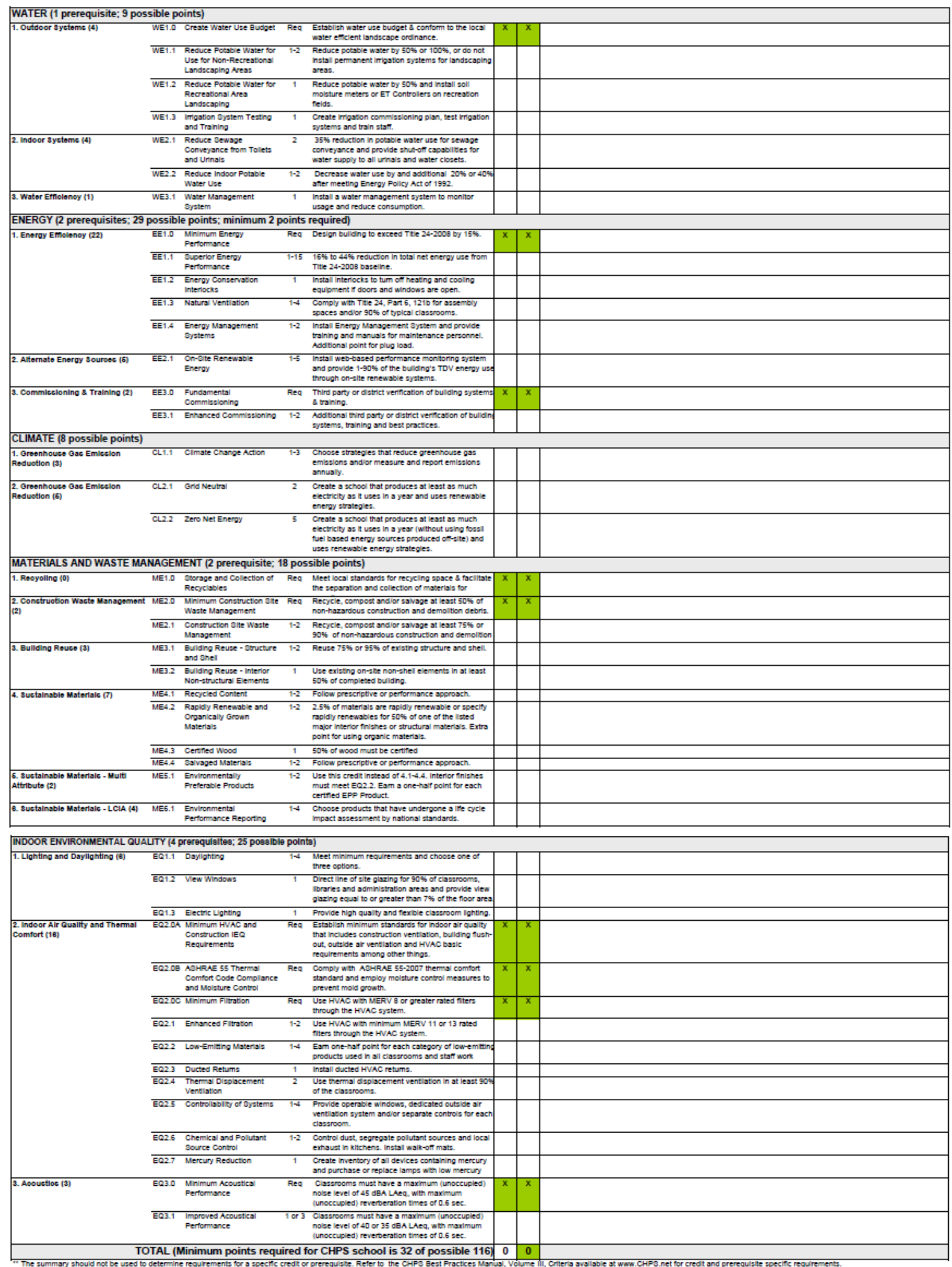


Appendix B. Pre-design and planning provided by the Beichuan team

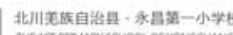

1.入口殿堂的尺寸加赛，使横向方向成为入口形急
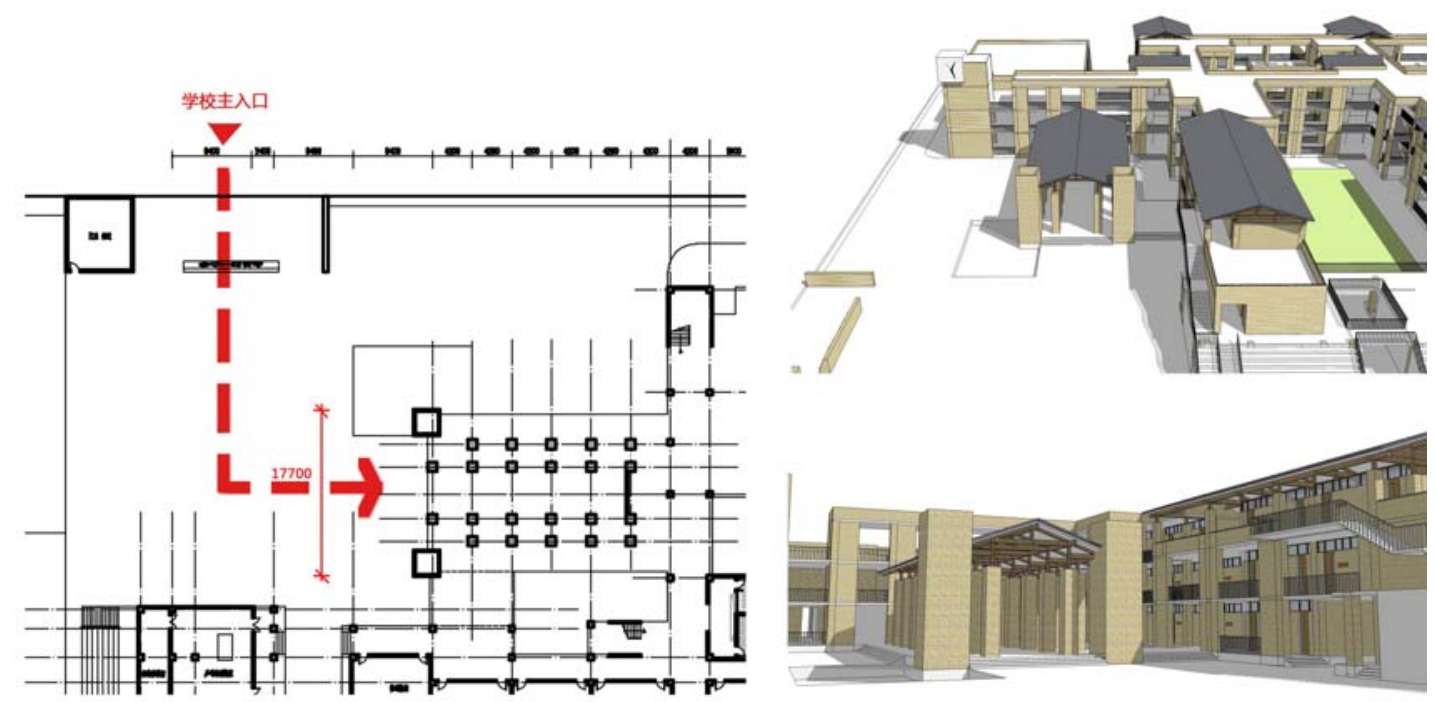

Figure 3 Yong Chang Elementary School

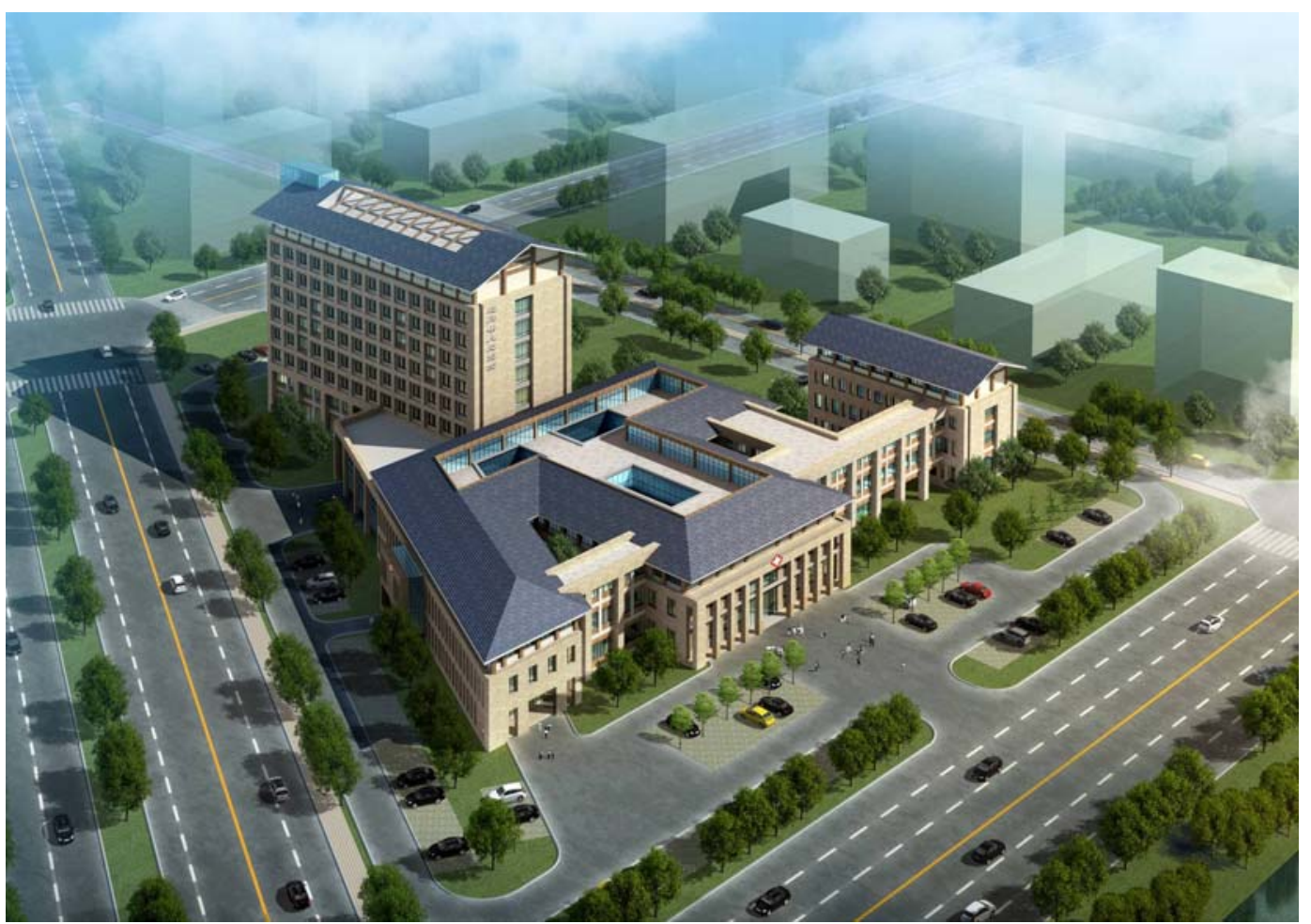

Figure 4 People’s Hospital 


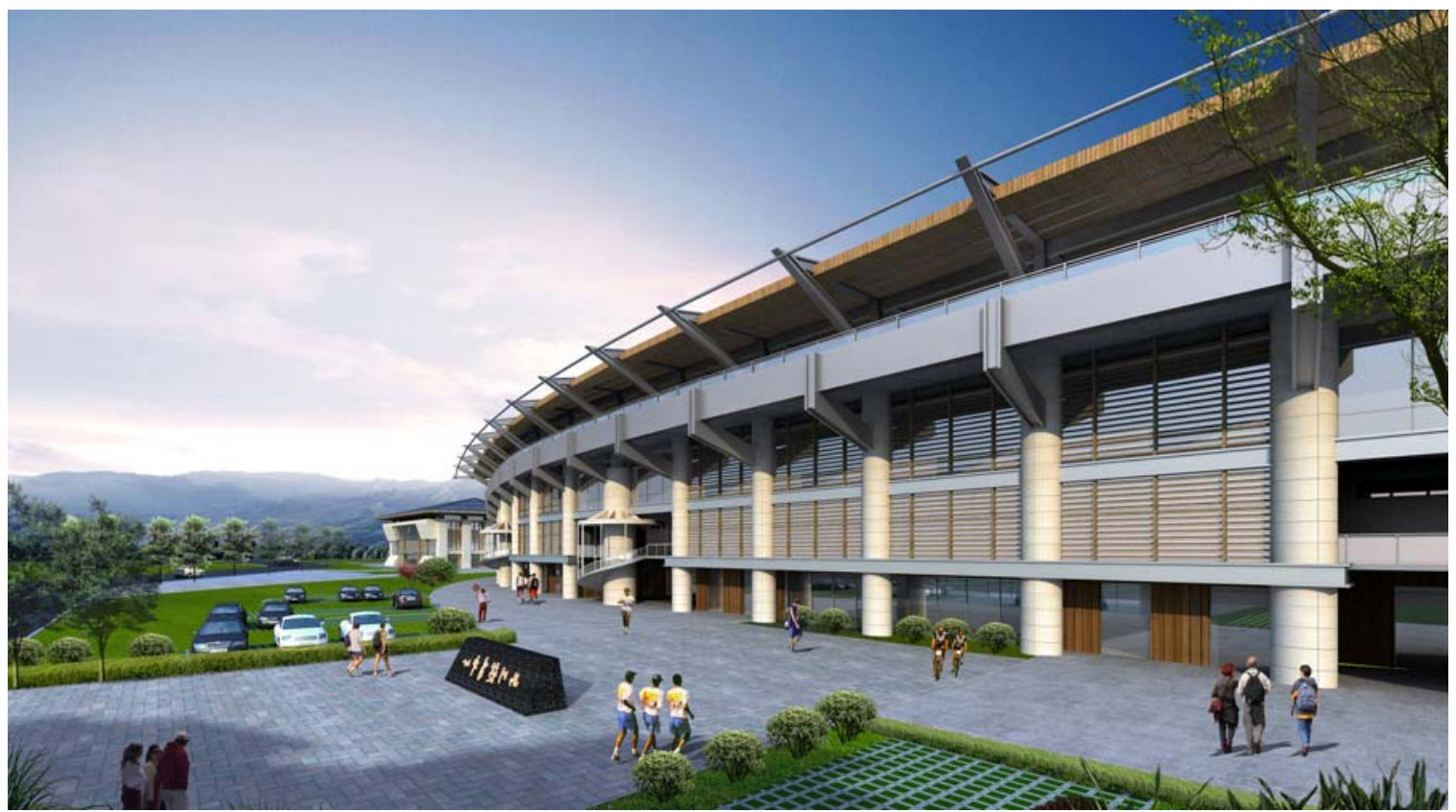

Figure 5 Sports Facility (stadium, training facility, and gym) 


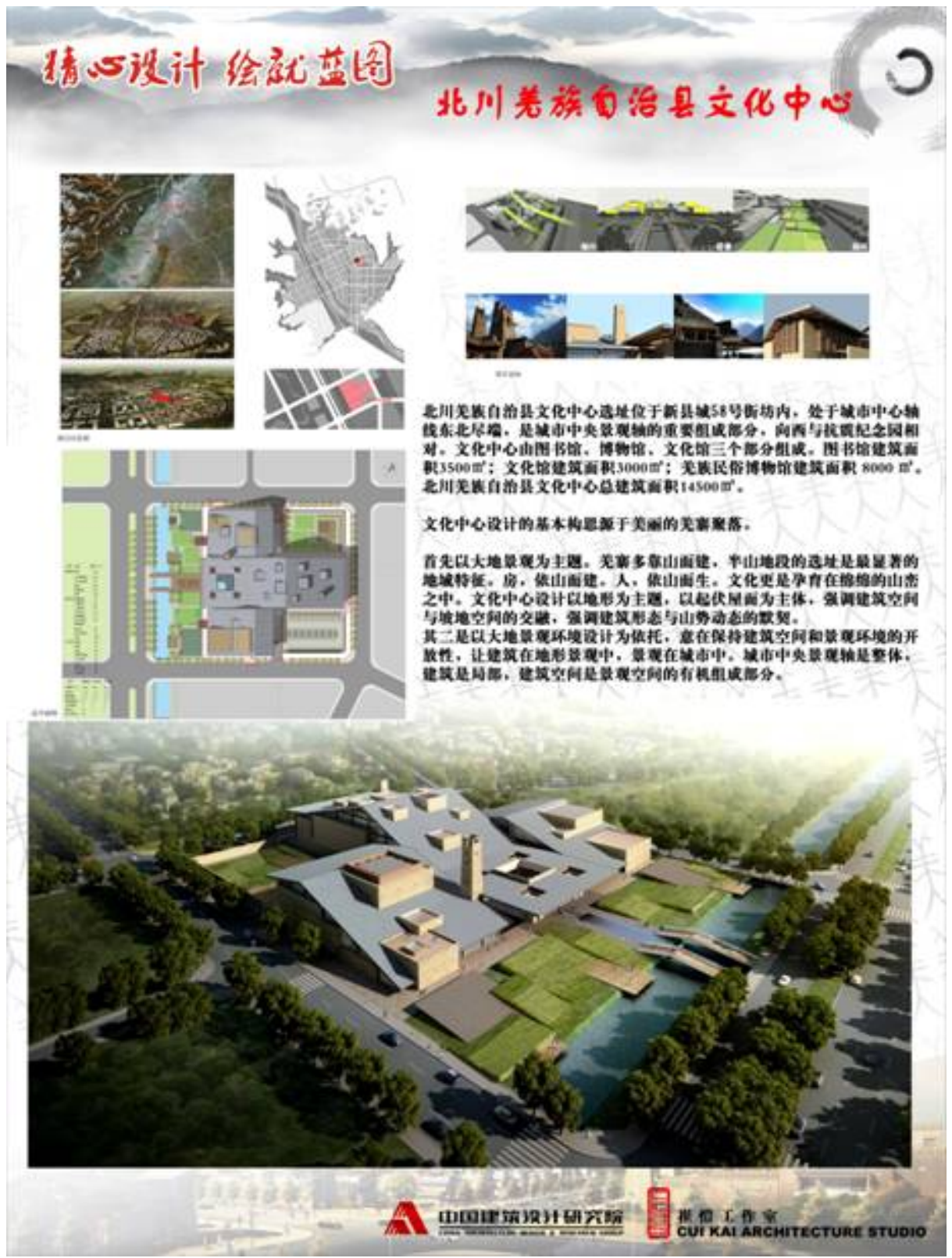

Figure 6 Qiang Culture Center 